CASE REPORT

\title{
Is the paraneoplastic syndrome of inappropriate antidiuretic hormone secretion in lung cancer always attributable to the small cell variety?
}

\author{
L M Tho, D R Ferry
}

Postgrad Med J 2005;81:el7 (http://www.postgradmedj.com/cgi/content/full/81/961/e17). doi: 10.1136/pgmj.2005.036889

The syndrome of inappropriate antidiuretic hormone (SIADH) secretion is a well recognised paraneoplastic phenomenon and the vast majority are associated with small cell lung carcinoma. Rarely however, the non-small cell variety can sometimes be responsible and this report describes such an occurrence. Uniquely in this case, after chemotherapy the paraneoplastic SIADH improved in parallel with a tumour response and this has not been reported previously.

A 56 year old man presented with a six month history of dyspnoea, cough, and weight loss. He had a 35 packyear history of smoking and a medical history of mild chronic obstructive pulmonary disease for which he was using inhaled bronchodilators. His Eastern Cooperative Oncology Group performance status was 2 .

A chest radiograph showed multiple nodular shadows throughout both lung fields and a right hilar mass-in keeping with an appearance of lymphangitis carcinomatosis (fig 1). A staging ultrasound of the abdomen and pelvis showed no extrathoracic disease. A bronchoscopy and biopsy showed a poorly differentiated non-small cell lung carcinoma (NSCLC) with some features suggesting an adenocarcinoma subtype. The histological findings were reviewed by two consultant histopathologists who confirmed the absence of any small cell elements.

At presentation, the biochemical profile showed a plasma sodium of $115 \mathrm{mmol} / \mathrm{l}$ (normal range 135 to 140 ), serum osmolality of $240 \mathrm{mOsmol} / \mathrm{kg}$, and urine osmolality of $495 \mathrm{mOmol} / \mathrm{kg}$. His other parameters showed a normal potassium, urea, creatinine, corrected calcium, thyroid function tests, liver function tests (albumin $35 \mathrm{~g} / \mathrm{l}$ ) and a C reactive protein of $36 \mathrm{mg} / \mathrm{l}$ and erythrocyte sedimentation rate of $35 \mathrm{~mm} \mathrm{lst} \mathrm{h.} \mathrm{A} \mathrm{recumbent} \mathrm{aldosterone} \mathrm{level} \mathrm{was}$ $202 \mathrm{pmol} / \mathrm{l}(28-445)$. Clinically he was euvolaemic, afebrile, and urine, sputum, and blood cultures were negative. There was no evidence of congestive cardiac failure or nephrotic syndrome. A diagnosis of syndrome of inappropriate antidiuretic hormone secretion (SIADH) was made.

He was treated with two courses of MIC chemotherapy (mitomycin $6 \mathrm{mg} / \mathrm{m}^{2}$, ifosfamide $3 \mathrm{~g} / \mathrm{m}^{2}$, and cisplatin $50 \mathrm{mg} / \mathrm{m}^{2}$ ) three weekly and after six weeks his plasma sodium was $130 \mathrm{mmol} / \mathrm{l}$. A chest radiograph showed a tumour response and he was less breathless and less fatigued. He received another two courses of MIC chemotherapy over the next six weeks. Along with further radiological (fig 2) and clinical improvement, his serum osmolality was $278 \mathrm{mOsmol} / \mathrm{kg}$ and plasma sodium was $132 \mathrm{mmol} / \mathrm{l}$. A few months later he was admitted for progressive disease and his plasma sodium was $120 \mathrm{mmol} / \mathrm{l}$. His condition did not improve and he eventually died shortly afterwards.

\section{DISCUSSION}

SIADH is a well recognised paraneoplastic phenomenon. In 1968, ADH was first extracted from cancer cells that led to the confirmation of this hypothesis. ${ }^{1}$ About $75 \%$ of tumour associated SIADH is caused by small cell lung cancer (SCLC). NSCLC is responsible for an exceedingly small proportion of paraneoplastic SIADH ${ }^{2}$-and in one case series of 427 NSCLC patients, only $0.7 \%$ of patients manifested SIADH. ${ }^{3}$ Not surprisingly, the occurrence of SIADH in NSCLC has rarely been reported and little is known about its clinical course. A literature review over the past 20 years found only two such published cases. ${ }^{45}$

In our patient, we were able to confirm a diagnosis of SIADH because of a low serum osmolality and hyponatraemia, a euvolaemic status with no diuretic use and no evidence of renal insufficiency, hypoadrenalism, hypothyroidism, infection, congestive cardiac failure, nephrotic syndrome, liver insufficiency, or other predisposing metabolic conditions. The paraneoplastic secretion of atrial naturetic peptide has been shown to affect sodium metabolism in cancer patients. However, the correlation between raised atrial naturetic peptide levels and concurrent hyponatraemia has not been well reported ${ }^{67}$ and its precise role is yet

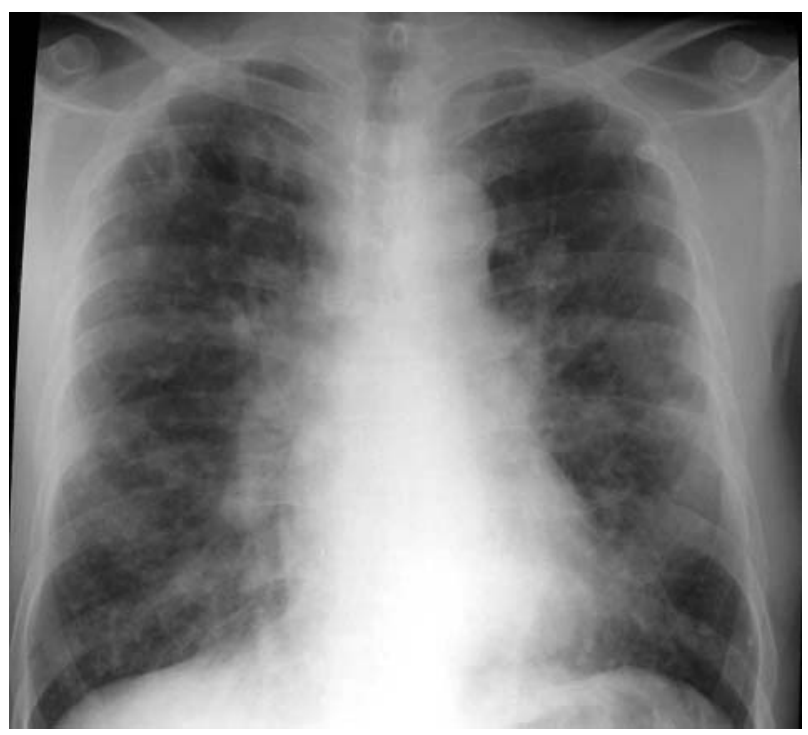

Figure 1 Chest radiograph showing the appearances of a right hilar mass and lymphangitis carcinomatosis.

Abbreviations: $\mathrm{SIADH}$, syndrome of inappropriate antidiuretic hormone secretion; NSCLC, non-small cell lung carcinoma; SCLC, small cell lung carcinoma 


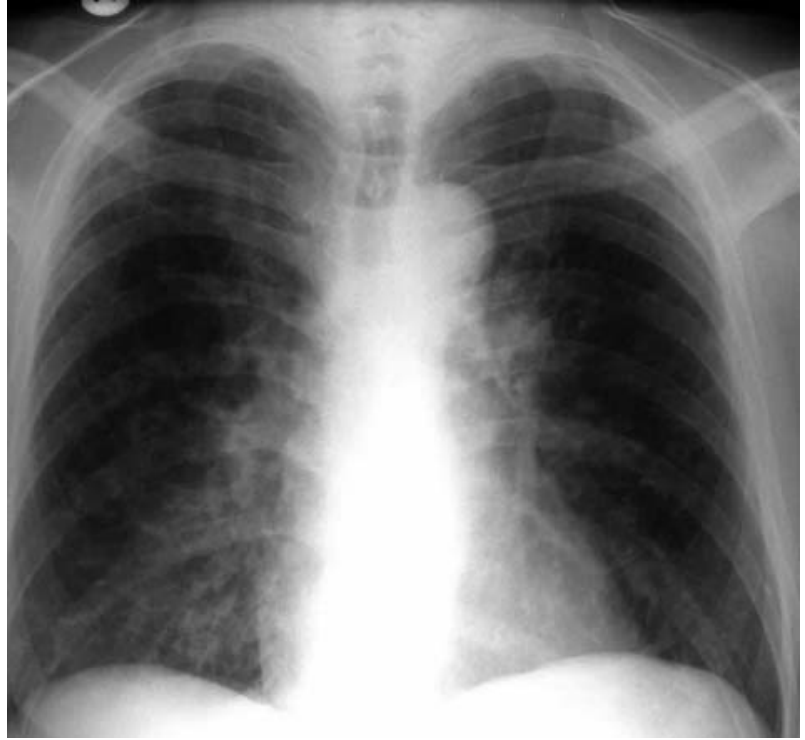

Figure 2 Chest radiograph after four cycles of chemotherapy showing a favourable radiological response to the treatment.

unknown. The occurrence of mixed cellularity within SCLC tumours has been described ${ }^{8}$; there are subtypes of SCLC that have a mixed NSCLC element. In our case, having obtained a sizable lung biopsy specimen, it would have been expected that the presence of small cell elements would be found if this was a mixed tumour.

Our case is unique as there was a correlation between a favourable clinical and radiological response to treatment of the lung cancer and an improvement in the hyponatraemia of SIADH. This has not been reported before. In one of the two reported cases of SIADH in NSCLC, there was resolution of SIADH after the surgical resection of the primary lung cancer. ${ }^{5}$ Cisplatin chemotherapy itself has been shown to cause SIADH, ${ }^{9}$ but of course in this patient's case, the hyponatraemia preceded the chemotherapy and instead, improved after its administration.

In conclusion, we report a case of SIADH occurring in NSCLC that continues to support the association between these two entities. In addition, our patient showed a response in the paraneoplastic metabolic condition of SIADH after palliative chemotherapy and this could suggest that chemotherapy may be a useful option in improving this condition.
Learning points

- The syndrome of inappropriate ADH (SIADH) secretion is suggested by hyponatraemia, low serum osmolality and high urine osmolality, or continued excretion of urine sodium, in the absence of other causes of hyponatraemia.

- Paraneoplastic SIADH is frequently associated with small cell lung cancer but there are reports of the nonsmall cell variety being responsible.

- It is possible that treatment for the cancer may improve this paraneoplastic condition.

\section{ACKNOWLEDGEMENTS}

The authors acknowledge the contribution made by Dr Simon Trotter, consultant histopathologist from the department of histopathology, Birmingham Heartlands Hospital, Birmingham.

\section{Authors' affiliations}

L M Tho, Beatson Oncology Centre, Glasgow, UK

D R Ferry, New Cross Hospital, Wolverhampton, UK

Correspondence to: $\operatorname{Dr} L$ M Tho, Beatson Oncology Centre, Glasgow G116NT, UK; lyemuntho@hotmail.com

Submitted 4 May 2005

Accepted 20 June 2005

\section{REFERENCES}

1 Vorherr H, Massry SG, Utiger RD, et al. Anti-diuretic principle in malignant tumour extracts from patients with inappropriate ADH syndrome. J Clin Endocrinol Metab 1968;28:162-8.

2 Peckham M. Pinedo $H$, Veronesi U. Oxford textbook of oncology. Oxford: Oxford University Press, 1995:2231-2.

3 Sorensen JB, Andersen, Hansen $\mathrm{HH}$. Syndrome of inappropriate secretion of antidiuretic hormone (SIADH) in malignant disease. J Intern Med 1995;238:97-110.

4 Monsieur I, Meysman M, Noppen M, et al. Non-small cell lung cancer with multiple paraneoplastic syndromes. Eur Respir J 1995;8:1231-4.

5 Katsuragi N, Shiraishi Y, Nakajima Y, et al. [Squamous cell bronchogenic carcinoma with syndrome of inappropriate secretion of antidiuretic hormone] Kyobu Geka 2004;57:847-50.

6 Campling BG, Sarda IR, Baer KA, et al. Secretion of atrial naturetic peptide and vasopressin by small cell lung cancer. Cancer 1995;75:2442-51.

7 Johnson BE, Chute JP, Rushin J, et al. A prospective study of patients with lung cancer and hyponatraemia of malignancy. Am J Respir Crit Care Med 1997; 156:1669-8.

8 DeVita Jr VT, Hellman S, Rosenberg SA. Cancer principles and practice of oncology. 6th ed. Philadelphia: Lippincott Williams and Wilkins, 2001:2514

9 Littlewood TJ, Smith AP. Syndrome of inappropriate antidiuretic hormone secretion due to treatment of lung cancer with cisplatin. Thorax 1984;39:636-7. 